(C2017, Elsevier. Licensed under the Creative Commons Attribution-NonCommercialNoDerivatives 4.0 International http://creativecommons.org/about/downloads

(9) $\odot \Theta \Theta$ 


\section{Diterpenoids from the Roots of Croton dichogamus Pax}

Areej Aldhaher ${ }^{\text {a, b}}$, Moses Langat ${ }^{\text {a, c }}$, Beth Ndunda ${ }^{\text {a, }}$, Denis Chirchir ${ }^{\text {e }}$, Jacob O. Midiwo ${ }^{\mathrm{d}}$, Alice Njue ${ }^{\mathrm{a}, \mathrm{e}}$, Sianne Schwikkard ${ }^{\mathrm{f}}$, Mark Carew ${ }^{\mathrm{f}}$, Dulcie Mulholland ${ }^{\mathrm{a}, \mathrm{c}, *}$

${ }^{a}$ Natural Products Research Group, Department of Chemistry, Faculty of Engineering and Physical Sciences, University of Surrey, Guildford GU2 7XH, United Kingdom

${ }^{\mathrm{b}}$ Department of Biology, College of Science, Basrah University, Basrah, Iraq

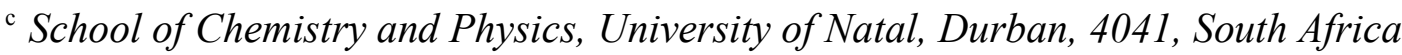

${ }^{\mathrm{d}}$ Department of Chemistry, University of Nairobi, P Bag 30197-00100, Nairobi, Kenya

e Department of Chemistry, Egerton University, P.O. Box 536, Njoro 20115, Kenya

${ }^{\mathrm{f}}$ Department of Chemistry, School of Life Sciences, Pharmacy and Chemistry, Kingston University, Penrhyn Road, Kingston, KT1 2EE, United Kingdom

* Corresponding author. Department of Chemistry, Faculty of Engineering and Physical Sciences, University of Surrey, Guildford GU2 7XH, United Kingdom.

E mail address: d.mulholland@surrey.ac.uk 


\begin{abstract}
:
Four previously undescribed diterpenoids including two crotofolanes, crotodichogamoin A and $\mathrm{B}$, and two halimanes, crothalimene $\mathrm{A}$ and $\mathrm{B}$, a new sesquiterpenoid, and fifteen previously reported compounds, including the crotofolane, crotohaumanoxide, the casbane, depressin, a further seven furanohalimane diterpenoids, three patchoulane and two further cadinane sesquiterpenoids and aleuritolic acid were isolated from the root of Croton dichogamus. Crotodichogamoin B is an important biosynthetic intermediate of the crotofolane class and this is the first report of patchoulene sesquiterpenoids from the genus. Compounds were tested at one concentration, $1 \times 10^{-5} \mathrm{M}$, in the NCI59 cell one-dose screen but did not show significant activity snd were also evaluated for their cytotoxicity against Caco-2 cell lines using the neutral red assay. 10-epi-Maninsigin D reduced Caco-2 cell viability at 10,30 and $100 \mu \mathrm{M}$, with values of decreased viability of $28 \%, 48 \%$ and $43 \%$ respectively. None of the other tested compounds showed significant activity.
\end{abstract}

Keywords:

Croton dichogamus, Euphorbiaceae, crotofolane, crotodichogamoin B, crothalimene A, crothalimene B, patchoulane, Caco-2 cell viability 


\section{Introduction}

The genus Croton is one of the largest of the Euphorbiaceae family with more than 1200 species occurring in the tropics and subtropics worldwide (Berry et al., 2005). Several species of Croton are used in South America, Asia and Africa in traditional medicine to treat abdominal pain, abscesses, dyspepsia, gastric and duodenal ulcers, impetigo, (Giang et al., 2003), diabetes, diarrhoea, and as an analgesic (Suárez et al., 2003), to treat dysmenorrhoea (Thongtan et al., 2003), respiratory diseases (Aguilar-Guadarrama and Rios, 2004), rheumatoid arthritis, snake bites, stomach aches, jaundice (Huang et al., 2015), wounds (Lopes et al., 2004; Salatino et al., 2007), as a tonic and to improve digestion (Asare et al., 2011), and as a mild laxative (Ngadjui et al., 1999). The sap of Croton lechleri Müll. Arg., known as "dragon's blood", is used as a household remedy to treat diarrhoea, stomach ulcers, pain and swelling of insect bites and herpes infections (Jones, 2003, Gupta et al., 2008; Sollmann, 1920). Phytochemical studies of Croton have shown the presence of alkaloids, phenolics, terpenoids and volatile oils, with a wide range of diterpenoid classes predominating (Salatino et al., 2007). Compounds from the Croton genus have been widely screened and have shown anti-angiogenic (Huang et al., 2015), antibacterial (Bayor et al., 2009), anti-inflammatory (Aguilar-Guadarrama and Rios, 2004), antinociceptive, (Suárez et al., ), antimalarial and antimycobacterial activity, and to show cytotoxicity towards Vero, KB and BC cell lines (Thongtan et al., 2003), to inhibit LPS-Induced NF-KB activation (Giang et al., 2003) and to be cytotoxic against human cervical carcinoma cells (Block et al., 2002).

Croton dichogamus Pax (Euphorbiaceae) grows as a shrub or tree in Ethiopia, Kenya, Madagascar, Mozambique, Tanzania and Somalia (Govaerts, 1999). This species is used as a dietary additive to milk or meat soup by the Maasai and Batemi of Kenya and Tanzania respectively. It is known as "Mhand" in Tanzania, where it is used to treat respiratory diseases by inhalation of smoke of the plant leaves (Mohagheghzadeh et al., 1999). It is used to treat chest complaints, malaria and stomach upsets in the Samburu region of Kenya, where it is commonly known as "l-akirding'ai" (Fratkin, 1996). In the Loitoktok district of Kenya, it is known as "Oloibor benek", and is used to treat arthritis and gonorrhoea (Muthee et al., 2011). A previous investigation of the leaves of $C$. dichogamus, collected in Kenya, led to the isolation two crotofolane diterpenoids, crotoxide A and B (Jogia et al., 1999). In the present study, the root gave five previously unreported compounds, crotodichogamoin A (2) and B (3), 15,16-epoxy-3-hydroxy-5(10), 13(16), 14-ent-halimatriene-17, 12(S)-olide (5), 15,16-epoxy-5,13(16),14-ent-halimatriene-3-ol (6), and 1,3,5-cadinatriene-(7R),(10S)-diol 
(19) together with 15 previously reported terpenoids. We report the structures of these five compounds, the previously unreported NMR data of the known compound 15,16-epoxy4(18),13(16),14-ent-clerodatrien-3 $\alpha$-ol (gbaninol) (11), along with the an evaluation of the cytotoxicity of compounds tested.

\section{Results and discussion}

The $n$-hexane, $\mathrm{CH}_{2} \mathrm{Cl}_{2}$ and $\mathrm{MeOH}$ extracts of the root of Croton dichogamus were separated using flash chromatography followed by preparative thin layer chromatography and/or gravity column chromatography to yield five previously unreported $(\mathbf{2}, \mathbf{3}, \mathbf{5}, \mathbf{6}$, and 19) and 15 known compounds. The known compounds were identified from their spectroscopic data and by comparison against literature data, as crotohaumanoxide (1) previously isolated from Croton haumanianus (Tchissambou et al., 1990), depressin (4), a casbain diterpenoid previously isolated from the soft coral Sinularia depressa (Li et al., 2010), 15,16-epoxy-

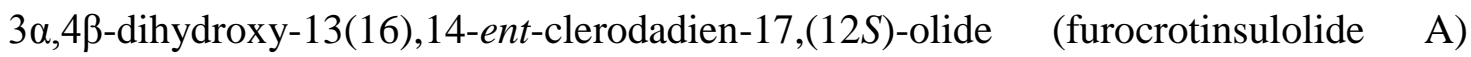
previously isolated from Croton insularis (Graikou et al., 2005), 15,16-epoxy-3-keto13(16),14-ent-clerodadien-17,(12S)-olide (crotonolide E) (8) and 15,16-epoxy-3 $\alpha$-hydroxy4(18),13(16),14-ent-clerodatrien-17,(12S)-olide (crotonolide F) (9) previously isolated from

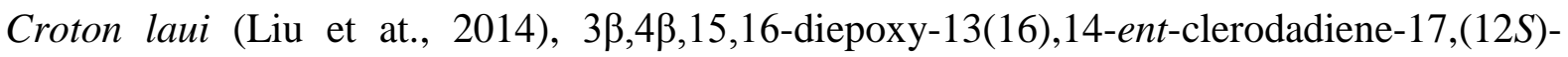
olide (10) previously isolated from Croton oblongifolius (Pudhom and Sommit; 2011), 15,16epoxy-4(18),13(16),14-ent-clerodatrien-3 $\alpha$-ol (gbaninol) (11), 15,16-epoxy-13(16),14-entclerodadien-3-one (trans-cascarillone) (12) previously isolated from Croton sonderianus

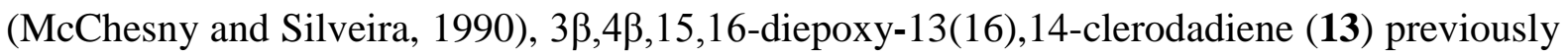
isolated from Thysananthus spathulistipus (Harinantenaina et al., 2006), 4-patchoulene (cyperene) (14) and 4-patchoulen-3-one (cyperotundone) (15) previously isolated from Cyperus rotundus (Joseph-Nathan et al., 1984; Xu et al., 2009), 6 $\alpha$-methoxypatchoulan-4-ene (16) previously isolated from Croton muscicapa (Barreto et al., 2013), 4-isopropyl-1,6dimethylnaphthalene (cadalene) (17) previously isolated from Siparuna macrotepala (El-

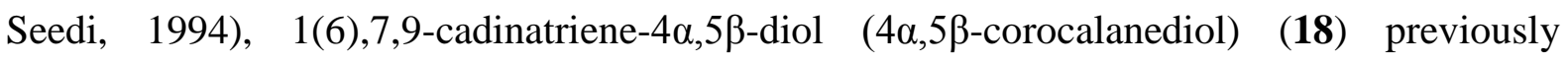
isolated from Juniperus formosana (Kuo et al., 1990), and aleuritolic acid (20) previously isolated from many sources, including C. pseudopulchellus (Langat et al., 2012). The structures of the patchoulenes (14-16) were determined with the assistance of the NMR Predict programme (Robien, 2014). This is the first report of patchoulene sesquiterpenoids from Croton. Gbaninol (11) has been isolated previously from Gossweilerodendron 
balsamiferum Harms (Caesalpiniaceae) (Ekong and Okogun, 1969), however, no NMR data has been reported for this compound.

The NMR spectra of compound 2 showed similarities to those of the co-isolated crotofolane, crotohaumanoxide (1) (Tchissambou et al., 1990). HREIMS data showed an $[\mathrm{M}+\mathrm{H}]^{+}$ion at $\mathrm{m} / \mathrm{z}, 327.1590$ indicating a molecular formula of $\mathrm{C}_{20} \mathrm{H}_{22} \mathrm{O}_{4}$. The FTIR spectrum showed absorption bands at $1747 \mathrm{~cm}^{-1}$ for a carbonyl stretch, $1649 \mathrm{~cm}^{-1}$ for a double bond stretch, and $1269 \mathrm{~cm}^{-1}$ for an epoxide $\mathrm{C}-\mathrm{O}$ stretch. The ${ }^{13} \mathrm{C}$ NMR spectrum showed twenty carbon resonances, which could be assigned using HSQC, COSY and HMBC experiments and by comparison with NMR data for crotohaumanoxide (1). The C-1 $\beta$ acetate group present in compound 1 was missing and a ketone group $\left(\delta_{C} 206.1\right)$ occurred at this position in compound 2 . The presence of a furan ring was shown by resonances at $\delta_{\mathrm{C}} 117.0$ $(\mathrm{C}-15), \delta_{\mathrm{C}} 121.8(\mathrm{C}-14), \delta_{\mathrm{C}} 137.0(\mathrm{C}-16)$ and $\delta_{\mathrm{C}} 150.4(\mathrm{C}-13)$ and the $\mathrm{C}-14, \mathrm{C}-15$ and $\mathrm{C}-16$ resonances showed correlations in the HMBC spectrum with the $3 \mathrm{H}-17$ resonance $\left(\delta_{\mathrm{H}} 1.96\right)$. The two $\mathrm{H}-12$ resonances $\left(\delta_{\mathrm{H}} 2.81,2.95\right)$ showed correlations in the HMBC spectrum with the $\mathrm{C}-10\left(\delta_{\mathrm{C}} 141.9\right), \mathrm{C}-11\left(\delta_{\mathrm{C}} 37.8\right), \mathrm{C}-13$ and $\mathrm{C}-14$ resonances and correlations in the COSY spectrum with two H-11 resonances $\left(\delta_{\mathrm{H}} 2.53,2.78\right)$. A pair of exomethylene proton resonances $\left(\delta_{\mathrm{H}} 5.06,4.67\right.$, bs, $\left.2 \mathrm{H}-18\right)$ showed correlations in the HMBC spectrum with the C-8 $\left(\delta_{\mathrm{C}} 39.8\right), \mathrm{C}-10$ and $\mathrm{C}-11$ resonances, confirming its placement at C-10. The C-18 resonance $\left(\delta_{\mathrm{C}} 116.9\right)$ showed correlations with the $\mathrm{H}-8$ and two $\mathrm{H}-11$ resonances, and the $\mathrm{H}-8$ resonance showed further correlations with the C-1 $\left(\delta_{\mathrm{C}} 206.1\right), \mathrm{C}-4\left(\delta_{\mathrm{C}} 65.8\right), \mathrm{C}-6\left(\delta_{\mathrm{C}} 61.5\right)$, C-7 $\left(\delta_{\mathrm{C}} 49.0\right), \mathrm{C}-9\left(\delta_{\mathrm{C}} 66.1\right), \mathrm{C}-10$ and C-14 resonances and a correlation in the COSY spectrum with the $\mathrm{H}-7$ resonance $\left(\delta_{\mathrm{H}} 2.49, \mathrm{~d}, J=13.0 \mathrm{~Hz}\right)$. The H-7 resonance showed correlations in the HMBC spectrum with the C-5 $\left(\delta_{C} 56.2\right), C-6, C-8, C-9, C-10, C-13, C-14$, C-15 and C-20 resonances. The chemical shifts of the C-9/C-4 and C-5/C-6 resonances indicated the presence of epoxides at these positions as in crotohaumanoxide. The H-5 resonance occurred as a singlet $\left(\delta_{\mathrm{H}} 3.29\right)$ and its assignment was confirmed by correlations with the C-4, C-6, C-9 and methyl C-20 $\left(\delta_{\mathrm{C}} 8.9\right)$ resonances. Both the C-4, C-9 and ketone carbon resonance showed correlations in the HMBC spectrum with the H-2 $\left(\delta_{\mathrm{H}} 2.49\right)$ and two H-3 $\left(\delta_{\mathrm{H}} 2.66\right.$ and 1.84) proton resonances. The $3 \mathrm{H}-19$ resonance $\left(\delta_{\mathrm{H}} 1.11\right.$, d) showed correlations in the HMBC spectrum with the C-2, C-3 and the ketone carbon resonance, confirming the placement of the keto group at $\mathrm{C}-1$. The COSY spectrum showed coupling between the $3 \mathrm{H}-19 / \mathrm{H}-2$ and $\mathrm{H}-2 /$ two $\mathrm{H}-3$ resonances. The relative configuration was assigned using the NOESY spectrum. Correlations were seen between the H-5/3H-20, $3 \mathrm{H}-$ 
20/H-8 and H-8/3H-17 resonances, and, therefore, they were assigned as $\beta$ as in crotohaumanoxide (1). Configurations at C-4 and C-9 could not be confirmed from the NOESY spectrum, but it was assumed that they would be the same as in the co-isolated crotohaumanoxide and the related crotocascarin A (Kawakami et al., 2013) with both the epoxide groups on the $\alpha$-face. In both crotohaumanoxide and crotocascarin $\mathrm{A}$ the relative configuration was confirmed by X-ray analysis.

Compound $\mathbf{3}$, crotodichogamoin $\mathrm{B}$, isolated as a yellow oil from the $\mathrm{CH}_{2} \mathrm{Cl}_{2}$ extract, was found to be an interesting crotofolane diterpenoid and a possible parent to the crotofolane class. The HRMS data showed a $[\mathrm{M}+\mathrm{H}]^{+}$ion at $\mathrm{m} / z 295.1694$ indicating a molecular formula of $\mathrm{C}_{20} \mathrm{H}_{22} \mathrm{O}_{2}$ and ten degrees of unsaturation. The FTIR spectrum showed a strong carbonyl stretch band at $1730 \mathrm{~cm}^{-1}$. The ${ }^{13} \mathrm{C}$ NMR spectrum showed twenty carbon resonances, including two ketone group carbon resonances at $\delta_{\mathrm{C}} 208.1$ (C-1) and $\delta_{\mathrm{C}} 202.5$ (C-13). Resonances due to furan ring carbons, present in $\mathbf{1}$ and $\mathbf{2}$, were not present. Vinyl methyl groups occurred at C-16 $\left(\delta_{\mathrm{C}} 23.5\right)$ and $\mathrm{C}-17\left(\delta_{\mathrm{C}} 22.1\right)$ and the HMBC spectrum showed correlations between the corresponding $3 \mathrm{H}-16\left(\delta_{\mathrm{H}} 1.49\right), 3 \mathrm{H}-17\left(\delta_{\mathrm{H}} 2.13\right)$ and $\mathrm{C}-15\left(\delta_{\mathrm{C}} 147.5\right)$ and $\mathrm{C}-14\left(\delta_{\mathrm{C}} 134.3\right)$ alkene carbon resonances. The HMBC spectrum showed correlations between the C-14 and C-13 $\left(\delta_{\mathrm{C}} 202.5\right)$ ketone carbonyl carbon resonance and the two $\mathrm{H}-12$ resonances $\left(\delta_{\mathrm{H}} 2.27\right.$ and $\left.\delta_{\mathrm{H}} 2.43\right)$. The $\mathrm{C}-13$ resonance also showed a correlation with the two $\mathrm{H}-11$ resonances $\left(\delta_{\mathrm{H}} 2.82\right.$ and $\left.\delta_{\mathrm{H}} 2.72\right)$, which showed correlations with the C-10 $\left(\delta_{\mathrm{C}}\right.$ 142.0) and C-18 ( $\delta_{C}$ 114.8) resonances of the exomethylene group and the C-8 (139.2) aromatic ring carbon resonance. The $3 \mathrm{H}-20$ resonance showed correlations with $\mathrm{C}-5$ methine $\left(\delta_{\mathrm{C}} 126.9\right)$ and $\mathrm{C}-6\left(\delta_{\mathrm{C}} 137.9\right)$ and $\mathrm{C}-7\left(\delta_{\mathrm{C}} 143.4\right)$ fully substituted carbon resonances. The corresponding H-5 singlet resonance $\left(\delta_{\mathrm{H}} 7.22\right)$ showed correlations with the C-3 $\left(\delta_{\mathrm{C}} 34.4\right)$, C$4\left(\delta_{\mathrm{C}} 131.0\right), \mathrm{C}-6\left(\delta_{\mathrm{C}} 137.9\right), \mathrm{C}-7\left(\delta_{\mathrm{C}} 143.4\right), \mathrm{C}-9\left(\delta_{\mathrm{C}} 153.3\right)$ and C-20 $\left(\delta_{\mathrm{C}} 20.6\right)$ resonances. The C-1 $\left(\delta_{\mathrm{C}} 208.0\right)$ ketone carbonyl resonance showed correlations with the two $\mathrm{H}-3\left(\delta_{\mathrm{H}}\right.$ $2.26,3.34)$, the $\mathrm{H}-2\left(\delta_{\mathrm{H}} 2.72\right)$ and $3 \mathrm{H}-19\left(\delta_{\mathrm{H}} 1.28, \mathrm{~d}, J=7.1\right)$ proton resonances in the HMBC spectrum. The H-2 resonance showed correlations with the C-4 $\left(\delta_{\mathrm{C}} 131.0\right)$ and C-9 $\left(\delta_{\mathrm{C}}\right.$ 153.5) resonances. The configuration at $\mathrm{C}-2$ in compound $\mathbf{3}$ was assumed to be the same as in compounds $\mathbf{1}$ and $\mathbf{2}$.

It has been proposed that crotofolones arise from geranylgeraniol cyclising to form cembranoids, from which casbenes, such as $\mathbf{4}$ co-isolated in this work, form. Bond formation between $\mathrm{C} 4 / \mathrm{C}-9$ gives the lathrane class, and further $\mathrm{C}-7 / \mathrm{C}-8$ bond formation leads to the 
jatrophanes. Cleavage of the $\mathrm{C}-13 / \mathrm{C}-15$ bond leads to the formation of the crotofolanes (Kawakami et al., 2013). Oxidation to a keto-group at C-13 and cyclisation with C-16 leads to the formation of a furan ring. Intermediates to the furan ring formation have been reported from C. inularis (Maslovskaya et al., 2014).

Compound 5, 15,16-epoxy-3ß-hydroxy-5(10),13(16),14-ent-halimatriene-17,(12S)-olide, isolated as a white solid from the $\mathrm{CH}_{2} \mathrm{Cl}_{2}$ extract, was found to be a previously undescribed furanohalimane diterpenoid. The HREIMS data showed a $[\mathbf{M}]^{+}$ion at $m / z$ 330.1830, indicating a molecular formula of $\mathrm{C}_{20} \mathrm{H}_{26} \mathrm{O}_{4}$. The FTIR spectrum showed absorption bands at $3436 \mathrm{~cm}^{-1}$ for an $\mathrm{OH}$ stretch, $1731 \mathrm{~cm}^{-1}$ for a carbonyl stretch and $1246 \mathrm{~cm}^{-1}$ for a C-O stretch. The ${ }^{1} \mathrm{H}$ NMR spectrum displayed three coupled broad singlet proton resonances at $\delta_{\mathrm{H}} 6.42$ $(\mathrm{H}-14), \delta_{\mathrm{H}} 7.45(\mathrm{H}-16)$ and $\delta_{\mathrm{H}} 7.41(\mathrm{H}-15)$, indicative of a $\beta$-substituted furan ring. An oxymethine proton resonance at $\delta_{\mathrm{H}} 5.47(\mathrm{dd}, J=5.0,12.0)$, which corresponded to the carbon resonance at $\delta_{\mathrm{C}} 72.4$, was assigned as $\mathrm{H}-12$ as it showed correlations in the HMBC spectrum with the $\mathrm{C}-13\left(\delta_{\mathrm{C}} 125.9\right), \mathrm{C}-14\left(\delta_{\mathrm{C}} 108.8\right)$ and $\mathrm{C}-16(139.7)$ resonances. The $\mathrm{H}-12$ resonance also showed correlations with a lactone carbonyl carbon resonance $\left(\delta_{\mathrm{C}} 172.8\right)$ assigned as $\mathrm{C}$ 17 , and the $\mathrm{C}-10$ resonance $\left(\delta_{\mathrm{C}} 132.1\right)$. The $\mathrm{C}-17$ resonance showed correlations with the $\mathrm{H}-8$ $\left(\delta_{\mathrm{H}} 2.31\right)$ and two $\mathrm{H}-7$ resonances, and correlations were seen between the C-10 and $3 \mathrm{H}-20$ $\left(\delta_{\mathrm{H}} 1.19\right)$ and $\mathrm{H}-8$ resonances. The $\mathrm{H}-3$ oxymethine proton resonance at $\left(\delta_{\mathrm{H}} 3.46\right)$ showed correlations with the C-18 $\left(\delta_{\mathrm{C}} 20.4\right)$ and C-19 (24.5) methyl carbon resonances, $\mathrm{C}-1\left(\delta_{\mathrm{C}} 24.3\right)$ and C-2 $\left(\delta_{\mathrm{C}} 27.3\right)$ methylene carbon resonances and C-4 and C-5 carbon resonances $\left(\delta_{\mathrm{C}} 39.8\right.$ and $\delta_{C}$ 135.1. The placement of the double bond between $C-5$ and $C-10\left(\delta_{C} 132.1\right)$ was confirmed by correlations between the $\mathrm{C}-10$ and the $2 \mathrm{H}-1\left(\delta_{\mathrm{H}} 2.08\right)$, one of the $\mathrm{H}-2\left(\delta_{\mathrm{H}} 1.81\right)$, $2 \mathrm{H}-6\left(\delta_{\mathrm{H}} 2.11\right.$ and 2.22$)$ and $2 \mathrm{H}-11\left(\delta_{\mathrm{H}} 1.82\right.$ and 2.32$)$ resonances and between the C-5 and the $2 \mathrm{H}-1, \mathrm{H}-3, \mathrm{H}-6$ and $\mathrm{H}-7$ proton resonances The coupling constants of the $\mathrm{H}-3$ resonance $\left(\delta_{\mathrm{H}} 3.46\right.$, dd, $J=3.3,11.7 \mathrm{~Hz}$ ) indicated the $\alpha$-orientation of H-3 (De, 1987; Graikou et al., 2005; Jones et al, 2007; Pudhom and Sommit, 2011). Correlations were seen between the H$3 / 3 \mathrm{H}-19,3 \mathrm{H}-19 / 3 \mathrm{H}-20,3 \mathrm{H}-20 / \mathrm{H}-12$ resonances and therefore, these were confirmed to be on the $\alpha$-face. The specific rotation for compound 5 was found to be +56.4 , indicating the compound belonged to the ent-series (Hara et al., 1995).

The HREIMS data for compound 6 gave a molecular formula of $\mathrm{C}_{20} \mathrm{H}_{30} \mathrm{O}_{2}$ for the compound $\left([\mathrm{M}+\mathrm{Na}]^{+}\right.$at $m / z$ 325.2138). The FTIR spectrum showed absorption bands at $3424 \mathrm{~cm}^{-1}$ for an $\mathrm{OH}$ stretch. Three coupled proton resonances at $\delta_{\mathrm{H}} 6.28(\mathrm{H}-14), \delta_{\mathrm{H}} 7.35(\mathrm{H}-$ 
15) and at $\delta_{\mathrm{H}} 7.22(\mathrm{H}-16)$ showed that a $\beta$-substituted furan ring was present. These resonances showed coupling in the $\mathrm{HMBC}$ spectrum with a methylene $\mathrm{C}-12$ carbon resonance $\left(\delta_{\mathrm{C}} 18.5\right)$, and this, the absence of a lactone carbonyl carbon resonance, and the fact that four methyl groups were present in compound $\mathbf{6}$ as opposed to 3 in compound $\mathbf{5}$, indicated that the 17,12-lactone was not present. The corresponding $\mathrm{H}-12$ resonances $\left(\delta_{\mathrm{H}}\right.$ 2.36, 2H) were seen to be coupled to the two $\mathrm{H}-11$ resonances, which were not further coupled, confirming the halimane structure. Coupling was seen in the COSY spectrum between the $3 \mathrm{H}-17\left(\delta_{\mathrm{H}} 0.88, \mathrm{~d}, J=6.7\right) / \mathrm{H}-8, \mathrm{H}-8 / 2 \mathrm{H}-7\left(\delta_{\mathrm{H}} 1.85,1.90\right)$ and $\mathrm{H}-7 / \mathrm{H}-6\left(\delta_{\mathrm{H}} 5.56\right)$ resonances. Thus a double bond was placed at C-5 $\left(\delta_{\mathrm{C}} 142.5, \mathrm{C}-5 ; \delta_{\mathrm{C}} 121.0, \mathrm{C}-6\right)$. The C-5 resonance showed correlations in the HMBC spectrum with the $\mathrm{H}-3\left(\delta_{\mathrm{H}} 3.49\right), 3 \mathrm{H}-18\left(\delta_{\mathrm{H}}\right.$ 1.07), $3 \mathrm{H}-19\left(\delta_{\mathrm{H}} 1.15\right)$ and $\mathrm{H}-10\left(\delta_{\mathrm{H}} 2.31\right)$ resonances. The $\mathrm{C}-10$ resonance $\left(\delta_{\mathrm{C}} 39.0\right)$ showed correlations with the $3 \mathrm{H}-20\left(\delta_{\mathrm{H}} 0.71\right)$ and $\mathrm{H}-6$ resonances.

The H-3 resonance occurred as a broad singlet $\left(\delta_{\mathrm{H}} 3.49\right.$, brs $\left.\mathrm{W}_{1 / 2}=8.6\right)$, indicating a $\beta$ equatorial orientation (Graikou et al., 2005; Liu et al., 2004), supported by correlations seen in the NOESY spectrum between the $\mathrm{H}-3$ and both the $\mathrm{H}-2$ resonances $\left(\delta_{\mathrm{H}} 1.72\right.$ and 1.89$)$ (Graikou et al., 2005). The H-3 proton resonance also showed correlations in the NOESY spectrum with the $3 \mathrm{H}-18$ and $3 \mathrm{H}-19$ resonances. Correlations seen between the $\mathrm{H}-8\left(\delta_{\mathrm{H}}\right.$ $1.62) / \mathrm{H}-10\left(\delta_{\mathrm{H}} 2.31\right)$ and $\mathrm{H}-10 / 3 \mathrm{H}-18\left(\delta_{\mathrm{H}} 1.07\right)$ resonances confirmed that they were on the same face of the molecule.

Compound 19, isolated as a yellow oily material, was found to be the C-10 epimer of the known maninsigin D which was isolated previously from Manglietia insignis Rehd (Magnoliaceae) (Shang et al., 2013). The HREIMS data showed a $[\mathrm{M}-\mathrm{H}]^{+}$peak at $\mathrm{m} / \mathrm{z}$ 233.1550, indicating a molecular formula of $\mathrm{C}_{15} \mathrm{H}_{22} \mathrm{O}_{2}$ for the compound. The FTIR spectrum showed an $\mathrm{OH}$ stretch band at $3485 \mathrm{~cm}^{-1}$. The ${ }^{13} \mathrm{C}$ NMR spectrum showed six aromatic carbon resonances at $\delta_{\mathrm{C}} 120.9(\mathrm{C}-2), \delta_{\mathrm{C}} 122.5(\mathrm{C}-5), \delta_{\mathrm{C}} 128.2(\mathrm{C}-3), \delta_{\mathrm{C}} 137.5(\mathrm{C}-4)$, $\delta_{\mathrm{C}} 137.6(\mathrm{C}-1)$ and $\delta_{\mathrm{C}} 138.9(\mathrm{C}-6)$ for one benzene ring, two oxygenated fully substituted carbon resonances at $\delta_{\mathrm{C}} 75.9(\mathrm{C}-10)$ and $\delta_{\mathrm{C}} 80.2(\mathrm{C}-7)$, and two aliphatic methylene group carbon resonances at $\delta_{\mathrm{C}} 24.4(\mathrm{C}-8)$ and $\delta_{\mathrm{C}} 30.5(\mathrm{C}-9)$, four methyl group carbon resonances and one methine group carbon resonance. The ${ }^{1} \mathrm{H}$ NMR spectrum showed the presence of an isopropyl group at C-7 as in the co-isolated cadalene (17) and $4 \alpha, 5 \beta$-corocalanediol (18) with two doublet methyl group proton resonances at $\delta_{\mathrm{H}} 1.15(\mathrm{~d}, J=6.9 \mathrm{~Hz}, 3 \mathrm{H}-12)$ and $\delta_{\mathrm{H}} 1.21(\mathrm{~d}$, $J=6.9 \mathrm{~Hz}, 3 \mathrm{H}-13$ ) and one methine proton resonance at $\delta_{\mathrm{H}} 2.60$ (hept, $J=6.9 \mathrm{~Hz}, \mathrm{H}-11$ ). 
The H-11 resonance showed correlations in the HMBC spectrum with the C-6, C-7 and C-8 resonances. A singlet methyl group proton resonance at $\delta_{\mathrm{H}} 1.64(3 \mathrm{H}-14)$ displayed correlations with the C-1, C-10, and C-9 $\left(\delta_{\mathrm{C}} 30.5\right)$ resonances, confirming its assignment. The COSY spectrum showed coupling between the $\mathrm{H}-2\left(\delta_{\mathrm{H}} 7.21, \mathrm{~d}, J=8.0 \mathrm{~Hz}\right)$ and $\mathrm{H}-3 \delta_{\mathrm{H}}$ $(7.18, \mathrm{~d}, J=8.0 \mathrm{~Hz})$ resonances and between the two $\mathrm{H}-8\left(\delta_{\mathrm{H}} 2.36, \delta_{\mathrm{H}} 1.49\right)$ and the two H-9 $\left(\delta_{\mathrm{H}} 1.59\right.$ and $\left.\delta_{\mathrm{H}} 2.26\right)$ methylene proton resonances. Thus the structure of this compound was shown to be 1,3,5-cadinatriene-7,10-diol. Four possible diastereomers are possible, one of which, 1,3,5-cadinatriene-7 $\beta, 10 \beta$-diol (maninsigin D), has been reported (Shang et al., 2013). In order to confirm the structure, a ${ }^{13} \mathrm{C}$ NMR spectrum was run in $\mathrm{CD}_{3} \mathrm{OD}$ to compare with the literature data of maninsigin D. Comparison of ${ }^{13} \mathrm{C}$ NMR chemical shifts of spectra run in $\mathrm{CD}_{3} \mathrm{OD}$ showed differences especially at C-10, C-7 and C-14 which occurred at $\delta_{\mathrm{C}} 81.6, \delta_{\mathrm{C}}$ 77.3 and $\delta_{\mathrm{C}} 19.5$ for compound 19 , and $\delta_{\mathrm{C}} 73.5, \delta_{\mathrm{C}} 70.1$ and $\delta_{\mathrm{C}} 28.8$ respectively for maninsigin D. Shang et al. used ROESY experiments to assign the relative configuration of maninsigin $\mathrm{D}$, and concluded that the $3 \mathrm{H}-14$ and the isopropyl groups were $c i$ s to each other. The NOESY spectrum of $\mathbf{1 9}$ showed no correlations between the $3 \mathrm{H}-14$ resonance and the isopropyl group proton resonances $(\mathrm{H}-11,3 \mathrm{H}-12$ and $3 \mathrm{H}-13)$ as seen for manginsigin $\mathrm{D}$, and this, in conjunction with the difference in ${ }^{13} \mathrm{C}$ NMR chemical shifts, suggested that the $3 \mathrm{H}-14$ and the isopropyl group were trans to each other. Therefore, the absolute stereo structure for compound 19 would be either $(7 R, 10 S)(\mathbf{1 9 A})$ or $(7 S, 10 R)(\mathbf{1 9 B})$. The specific rotation for compound 19 was -96.0 , compared to -9.4 reported for maninsigin D.

The absolute configuration of compound $\mathbf{1 9}$ was determined using electronic circular dichroism (ECD) studies. The experimental ECD curve showed negative Cotton effects at $201 \mathrm{~nm}(-18.68)$ and $307 \mathrm{~nm}(-4.12)$ for compound 19. The experimental ECD data was compared with calculated ECD curves for 3,5-cadinatriene-(7R,10S)-diol (19A) and 1,3,5cadinatriene-(7S,10R)-diol (19B). A systematic analysis of conformer distribution using the molecular mechanics force fields (MMFF) at ground state was undertaken using Spartan14 software. MMFF analysis of 3,5-cadinatriene-(7R,10S)-diol (19A) gave 25 conformers, 21 of which were under $3 \mathrm{kcal} / \mathrm{mol}$. The M0001 (-4.01 kcal/mol) conformer, which was consistent with the NOESY NMR experimental data and had a Boltzmann distribution of 0.775, was subjected to TDDFT calculations using a B3LYP method at 6-311G level built into Gaussian09 software. MMFF analysis of 1,3,5-cadinatriene-(7S,10R)-diol (19B) gave 24 conformers, 21 of which were under $3 \mathrm{kcal} / \mathrm{mol}$. The M0001 (-4.01 kcal/mol) conformer, which had a Boltzmann distribution of 0.777 , was subjected to TDDFT calculations using the 
B3LYP method at 6-311G level built into Gaussian09 software. The calculated ECD curves for both diastereomers were compared to the experimental ECD curve for compound 19. The calculated ECD curve of 19B was found to be opposite and equal in intensity to the experimental curve but the calculated ECD curve for 19A was similar, (Figure 2) confirming the structure as $1,3,5$-cadinatriene-(7R,10S)-diol.

Compounds $2,5,6,7,8,11,12,14,17,18,19,20$ were screened in vitro for cell viability against Caco-2 (human colorectal adenocarcinoma) cell lines using the neutral red assay (Repetto et al., 2008). The samples were tested at $100 \mu \mathrm{M}$ to estimate their cytotoxicity and compared with actinomycyin at a concentration of $7.96 \mu \mathrm{M}(10 \mu \mathrm{g} / \mathrm{ml})$ as a positive control as described in the Experimental Section. Only compound 19 reduced Caco-2 at 100 $\mu \mathrm{M}$ (Figure S4 in Supporting Information) and was further tested at five concentrations, 1, 3, 10, 30 and $100 \mu \mathrm{M}$. Compound 19 reduced cell viability at $10 \mu \mathrm{M}$ (Figure 3). None of the compounds isolated have been screened previously for cytotoxicity although maninsigin D has been tested against HL-60, A-549, SW-480, SMMC-7721 and MCF-7 human cell lines by the MTT method and showed $\mathrm{IC}_{50}$ values $>40 \mu \mathrm{M}$ (Shang et al., 2013) and the normal enantiomer of 12 showed cytotoxicity against BT-474, KATO-3, CHAGO, SW-620 and HEP-G2 human cancer cell lines with $\mathrm{LC}_{50}$ values of $3.26,6.78,6.67,4.44$ and $6.37 \mu \mathrm{g} / \mathrm{mL}$ (Pudhom and Sommit, 2011).

Compounds 2, 3, 5, 6, 11, 12, 19 and 20 were evaluated against the NCI59 developmental therapeutics program 59 cancer cell line screen at one dose of $1 \times 10^{-5} \mathrm{M}(\mathrm{NCI}$ DTP Developmental Therapeutics Program, 2016). The compounds did not meet the criteria for further testing (Supporting Information).

The compounds isolated in this work are consistent with our previous investigations of African Croton species, which have been shown to yield a wide range of diterpenoid classes as the major constituents, along with sesquiterpenoids and common triterpenoids (Mulholland et al., 2010; Langat et al., 2011, 2012; Ndunda et al., 2016).

\section{Experimental section}

\subsection{General Experimental Procedures}

Optical rotations were measured at room temperature on a JASCO-P-1020 polarimeter and IR spectra were recorded using a Perkin-Elmer (2000 FTIR) spectrophotometer using KBr discs. ECD spectra were measured on a Chirsascan CD spectrometer. ${ }^{1} \mathrm{H},{ }^{13} \mathrm{C}$ and $2 \mathrm{D}$ 
NMR spectra were recorded on a Bruker AVANCE III NMR spectrometer, operating at $500.13 \mathrm{MHz}$ for ${ }^{1} \mathrm{H}$ and $125.76 \mathrm{MHz}$ for ${ }^{13} \mathrm{C}$, using standard experiments from the Bruker pulse programs library. Chemical shifts are reported in $\mathrm{ppm}(\delta)$ referencing the solvent signal $\left(\mathrm{CDCl}_{3}\right)$ as internal standard respect to TMS $(0 \mathrm{ppm})$, and coupling constants $(J)$ are measured in Hz. HREIMS was performed on a Bruker MicroToF Mass Spectrometer, using an Agilent 1100 HPLC to introduce samples.

\subsection{Plant Material}

The root of Croton dichogamus Pax was collected in Wamunya, in the Machakos area of Kenya $\left(1.41^{\circ} \mathrm{S}, 37.62^{\circ} \mathrm{E}\right)$ and identified by Mr. Patrick Mutiso of the University Herbarium, School of Biological Studies, University of Nairobi, Kenya. A voucher specimen (BN 2010/13) was deposited at the Herbarium, School of Biological Studies, University of Nairobi.

\subsection{Extraction and Isolation}

The ground root (1 kg) of Croton dichogamus Pax was extracted at room temperature on a shaker for 24 h successively with $n$-hexane, $\mathrm{CH}_{2} \mathrm{Cl}_{2}$ and $\mathrm{MeOH}$, to yield, after evaporation of the solvents, $n$-hexane $(8.5 \mathrm{~g}), \mathrm{CH}_{2} \mathrm{Cl}_{2}(20.0 \mathrm{~g})$ and $\mathrm{MeOH}(25.6 \mathrm{~g})$ extracts. The crude extracts were separated using medium pressure flash chromatography (Grace Reveleris X2) over silica gel using a $n$-hexane/ $\mathrm{CH}_{2} \mathrm{Cl}_{2} / \mathrm{MeOH}$ step gradient and collecting $20 \mathrm{~mL}$ fractions. The compounds were detected using an ELSD detector at three wavelengths, 320, 280 and $254 \mathrm{~nm}$. Subsequent purifications were carried out using preparative thin layer chromatography (silica gel 60 F254 coated aluminium backed TLC sheets) and/or $1 \mathrm{~cm}$ diameter column, which was packed with Sephadex ( $\mathrm{LH}$ 20) in $\mathrm{MeOH} / \mathrm{CH}_{2} \mathrm{Cl}_{2}$ or silica gel (Merck Art. 9385). Detailed extraction procedures are provided as Supporting Information (Schemes S1.1, S1.2 and S1.3). The $n$-hexane extract contained cadalene 17 (3.9 mg), 6 $\alpha$ methoxy-patchoulan-4-ene (6 $\alpha$-methoxycyperene) $16(7.7 \mathrm{mg})$, depressin 4 (6.0 mg),

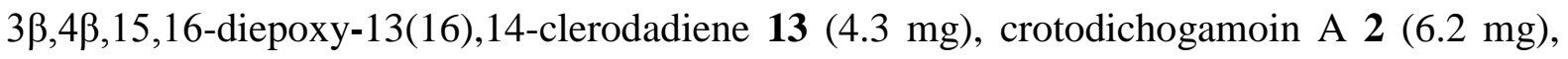
1,3,5-cadinatriene-(7R,10S)-diol $19(3.1 \mathrm{mg})$, crotodichogamoin B $3(8.0 \mathrm{mg}), 3 \beta, 4 \beta, 15,16$ diepoxy-13(16),14-ent-clerodadiene-17,(12S)-olide 10 (4.2 $\mathrm{mg})$, acetyl aleuritolic acid 20 (13.5 mg), 15,16-epoxy-3-hydroxy-5(10),13(16),14-ent-halimatriene-17,(12S)-olide 5 (2.8 $\mathrm{mg}$ ) and 4-patchoulen-3-one 15 (3.2 mg). The $\mathrm{CH}_{2} \mathrm{Cl}_{2}$ extract gave 4-patchoulene 14 (5.2 mg), 4-patchoulen-3-one 15 (1.7 mg), cadalene 17 (7.1 mg), 1,3,5-cadinatriene-(7R,10S)-diol 
19 (1.5 mg), 15,16-epoxy-13(16),14-ent-clerodadien-3-one 12 (7.5 mg), crotodichogamoin A 2 (3 mg), 15,16-epoxy-5,13(16),14-ent-halimatriene-3-ol 6 (1.8 mg), 15,16-epoxy4(18),13(16),14-ent-clerodatrien-3 $\alpha$-ol 11 (1.6 mg), acetyl aleuritolic acid 20 (3.3 mg), crotodichogamoin B 3 (2.9 mg), 15,16-epoxy-3-keto-3(16),14-ent-clerodadien-17,(12S)-olide 8 (10.2 mg), 15,16-epoxy-3 $\beta$-hydroxy-ent-halimatriene-17,(12S)-olide 5 (3.2 mg), 1(6),7,9-

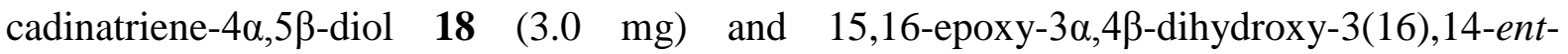
clerodadien-17,12S-olide 7 (15.4 mg). The MeOH extract gave 15,16-epoxy-3 $\alpha$-hydroxy-

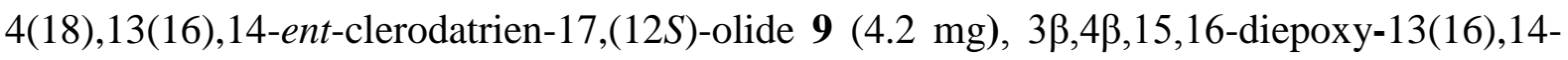
clerodadiene 13 (4.7 $\mathrm{mg})$ and crotohaumanoxide 1 (2.7 $\mathrm{mg})$.

\subsubsection{Crotodichogamoin A (2)}

Yellow gum; $[\alpha]^{23}{ }_{\mathrm{D}}+11.3\left(\mathrm{c} 0.020, \mathrm{CHCl}_{3}\right) ; \mathrm{IR}(\mathrm{KBr}) v_{\max } 2917,2848,1747,1649 \mathrm{~cm}^{-1}$; ${ }^{1} \mathrm{H}$ and ${ }^{13} \mathrm{C}$ NMR data, see Table 1; HREIMS $m / z 327.1590[\mathrm{M}+\mathrm{H}]^{+}\left(\right.$calcd for $\mathrm{C}_{20} \mathrm{H}_{22} \mathrm{O}_{4}+\mathrm{H}$, $m / z 327.1597)$.

\subsubsection{Crotodichogamoin B (3)}

Yellow oil; $[\alpha]^{23}{ }_{\mathrm{D}}+111.1\left(\mathrm{c} 0.001, \mathrm{CHCl}_{3}\right) ; \mathrm{IR}(\mathrm{KBr}) v_{\max } 2928,2856,1730,1594 \mathrm{~cm}^{-1}$; UV (ACN); $\lambda_{\max }=306,242,219 \mathrm{~nm} ;{ }^{1} \mathrm{H}$ and ${ }^{13} \mathrm{C}$ NMR data, see Table 1 ; HREIMS $\mathrm{m} / z$ 295.16945 $[\mathrm{M}+\mathrm{H}]^{+}$(calcd for $\mathrm{C}_{20} \mathrm{H}_{22} \mathrm{O}_{2}+\mathrm{H}, \mathrm{m} / z$ 295.1699).

\subsubsection{5,16-Epoxy-33-hydroxy-5(10),13(16),14-ent-halimatriene-17,(12S)-olide (5)}

White solid; $[\alpha]^{23}$ D $56.0(\mathrm{c} 0.036, \mathrm{MeOH}) ; \mathrm{IR}(\mathrm{KBr}) v_{\max } 3436,2936,2876,1731 \mathrm{~cm}^{-1}$; ${ }^{1} \mathrm{H}$ and ${ }^{13} \mathrm{C}$ NMR data, see Table 2; HREIMS $\mathrm{m} / \mathrm{z} 330.1830[\mathrm{M}]^{+}$(calcd for $\mathrm{C}_{20} \mathrm{H}_{26} \mathrm{O}_{4}, \mathrm{~m} / \mathrm{z}$ $330.1831)$.

\subsubsection{5,16-Epoxy-5,13(16),14-ent-halimatriene-3-ol (6):}

Yellow oil; $[\alpha]^{23}{ }_{\mathrm{D}}+40.5$ (c 0.032, MeOH); IR (KBr) $v_{\max } 3424,2922,2852 \mathrm{~cm}^{-1} ;{ }^{1} \mathrm{H}$ and ${ }^{13} \mathrm{C}$ NMR data, see Table 2; HREIMS $m / z 325.2138[\mathrm{M}+\mathrm{Na}]^{+}$(calcd for $\mathrm{C}_{20} \mathrm{H}_{30} \mathrm{O}_{2}+\mathrm{Na}, \mathrm{m} / z$ 325.2144).

\subsubsection{1,3,5-Cadinatriene-(7R,10S)-diol (10-epi-maninsigin D) (19)}


Yellow oil, $[\alpha]^{23}{ }_{\mathrm{D}}^{-96.0}$ (c 0.002,MeOH); IR (KBr) $v_{\max } 3485,2926,2857,1601 \mathrm{~cm}^{-1} ;{ }^{1} \mathrm{H}$ and ${ }^{13} \mathrm{C}$ NMR data, see Table 2; HREIMS $m / z 233.1550[\mathrm{M}-\mathrm{H}]^{+}$(calcd for $\mathrm{C}_{15} \mathrm{H}_{22} \mathrm{O}_{2}-\mathrm{H}, \mathrm{m} / z$ 233.1541).

\subsection{Cytotoxicity Assay}

Caco-2 human colon carcinoma cells (CACO-2 (ECACC 86010202) from Public Health England, UK) were cultured in Eagles' Modified Essential Medium supplemented with 10\% Foetal Bovine Serum, 2 mM glutamine, 1\% non-essential amino acids, $100 \mathrm{U} / \mathrm{ml}$ penicillin, $0.1 \mathrm{mg} / \mathrm{ml}$ streptomycin, and maintained in $5 \% \mathrm{CO}_{2} / 95 \%$ air in an incubator at $37^{\circ} \mathrm{C}$. Cells were plated in 96 well plates at $2 \times 10^{4}$ cells/well and incubated for 48 hours. Cells were then treated for 48 hours with one of the following, in 4 replicates: culture medium alone (untreated control); $0.1 \%$ DMSO (vehicle control; maximum DMSO exposed to cells); actinomycin D $10 \mu \mathrm{g} / \mathrm{ml}$ (positive control); test substances at 1, 3, 10, 30 and $100 \mu \mathrm{M}$ (diluted from a $100 \mathrm{mM}$ stock in DMSO). Cells were washed with PBS, and neutral red (25 $\mu \mathrm{g} / \mathrm{ml}$ in culture medium, diluted from a stock of $2.5 \mathrm{mg} / \mathrm{ml}$ in ultrapure water) was added for 3 hours, cells were washed with PBS, and neutral red extracted in 50\% ethanol/water with $1 \%$ acetic acid. Absorbance was read at $540 \mathrm{~nm}$. Data are from 2-3 independent experiments (different cell passages). The mean absorbance of wells without cells (blank) was subtracted from all other readings. Replicates were averaged to give one treatment value per plate. All plate treatment values were divided by the mean value of vehicle-treated cells on the same plate, so data was normalised as percentage of maximum cell viability.

\section{Acknowledgements}

Areej Aldaher thanks the Higher Committee For Education Development in Iraq for a Ph.D. scholarship to study at the University of Surrey, Alice Njue gratefully acknowledges a Commonwealth Split-Site PhD Scholarship and Beth Ndunda thanks University of Nairobi, International Foundation of Sciences (IFS), International Science Program (ISP-Sweden), Organization for Prevention of Chemical Weapons (OPCW), the Natural Products Research Network for East and Central Africa (NAPRECA) for supporting her PhD studies and Mr. Patrick Mutiso for identifying the plant material. We gratefully acknowledge The National Cancer Institute for NCI59 cancer cell screening and Mr C. Sparrow, Oxford University, for MS analysis.

\section{Appendix A. Supplementary data}


Supplementary data related to this article can be found at $\mathrm{xxxxx}$

\section{References}

Aguilar-Guadarrama, A. B., Rios, M. Y., 2004. Three new sesquiterpenes from Croton arboreous. J. Nat. Prod. 67, 914-917.

Asare, G. A., Sittie, A., Bugyei, K., Gyan, B. A., Adjei, S., Addo, P., Wiredu, E. K., Nyarko, A. K., Otu-Nyarko, L. S., Adjei, D. N., 2011. Acute toxicity studies of Croton membranaceus root extract. J. Ethnopharmacol. 134, 938-943.

Barreto, M. B., Gomes, C. L., Freitas, J. V. B. d., Pinto, F. d. C. L., Silveira, E. R., Gramosa, N. V., Torres, D. S. C., 2013. Flavonoides e terpenoides de Croton muscicarpa (Euphorbiaceae). Quím. Nova 36, 675-679.

Bayor, M. T., Gbedema, S. Y., Annan, K., 2009. The antimicrobial activity of Croton membranaceus, a species used in formulations for measles in Ghana. J. Pharmacognosy. Phytother. 1, 047-051.

Berry, P. E., Hipp, A.L., Wurdack, K.J., Van Ee, B., Riina, R., 2005. Molecular phylogenetics of the giant genus Croton and tribe Crotoneae (Euphorbiaceae sensu stricto) using ITS and trnL-trnF DNA sequence data. Am. J. Bot. 92, 1520-1534.

Block, S., Stevigny, C., De Pauw-Gillet, M., de Hoffmann, E., Llabres, G., Adjakidje, V., Quetin-Leclercq, J., 2002. ent-Trachyloban-3 $\beta$-ol, a new cytotoxic diterpene from Croton zambesicus. Planta Med. 68, 647-649.

De, P. T., Urones, J. G., Marcos, I. S., Basabe, P., Cuadrado, M. J. S., Fernandez Moro, R., 1987. Triterpenes from Euphorbia broteri. Phytochemistry 26, 1767-1776.

Ekong, D. E. U., Okogun, J. I., 1969. West African timbers. Part XXV. Diterpenoids of Gossweilerodendron balsamiferum harms. J. Chem. Soc. C, 2153-2156.

El-Seedi, H., Ghia, F., Torssell, K. B. G., 1994. The international journal of plant biochemistry Cadinane sesquiterpenes from Siparuna macrotepala. Phytochemistry 35, 1495-1497.

Fratkin, E., 1996. Traditional medicine and concepts of healing among Samburu pastoralists of Kenya. J. Ethnobiol. 16, 63-97.

Giang, P. M., Jin, H. Z., Son, P. T., Lee, J. H., Hong, Y. S., Lee, J. J., 2003. ent-Kaurane diterpenoids from Croton tonkinensis inhibit LPS-Induced NF- $\kappa \mathrm{B}$ activation and no production. J. Nat. Prod. 66, 1217-1220. 
Govaerts, R.; 1999. World checklist of Euphorbiaceae. Facilitated by the Royal Botanic Gardens, Kew. http://apps.kew.org/wcsp/namedetail.do?name_id=49769 (accessed 0701-2016).

Graikou, K., Aligiannis, N., Chinou, I., Skaltsounis, A.-L., Tillequin, F., Litaudon, M. , 2005. Chemical constituents from Croton insularis. Helv. Chim. Acta 88, 2654-2660.

Gupta, D., Bleakley, B., Gupta, R. K., 2008. Dragon's blood: botany, chemistry and therapeutic uses. J. Ethnopharmacol. 115, 361-380.

Hara, N., Asaki, H., Fujimoto, Y., Gupta, Y. K., Singh, A. K., Sahai, M., 1995. Clerodane and ent-halimane diterpenes from Polyalthia longifolia. Phytochemistry 38, 189-194.

Harinantenaina, L., Takahara, Y., Nishizawa, T., Kohchi, C., Soma, G.-I., Asakawa, Y. Chemical Constituents of Malagasy Liverworts, Part V: Prenyl Bibenzyls and Clerodane Diterpenoids with Nitric Oxide Inhibitory Activity from Radula appressa and Thysananthus spathulistipus. Chem. Pharm. Bull. 2006, 54, 1046-1049.

Huang, W., Wang, J., Liang, Y., Ge, W., Wang, G., Li, Y., Yin Chung, H., 2015. Potent antiangiogenic component in Croton crassifolius and its mechanism of action. J. Ethnopharmacol. 175, 185-191.

Jogia, M. K., Andersen, R. J., Parkanyi, L., Clardy, J., Dublin, H. T., Sinclair, A. R. E., 1989. Crotofolane diterpenoids from the African shrub Croton dichogamus Pax. J. Org. Chem. 54, 1654-1657.

Jones, K., 2003. Review of sangre de drago (Croton lechleri) - a South American tree sap in the treatment of diarrhea, inflammation, insect bites, viral Infections, and wounds: traditional uses to clinical research. J. Altern. Complement. Med. 9, 877-896.

Jones, W. P., Lobo-Echeverri, T., Mi, Q., Chai, H.-B., Soejarto, D. D., Cordell, G. A., Swanson, S. M., Kinghorn, A. D., 2007. Cytotoxic constituents from the fruiting branches of Callicarpa americana collected in Southern Florida,1. J. Nat. Prod. 70, 372-377.

Joseph-Nathan, P., Martińez, E., Santillan, R. L., Wesener, J. R., Günther, H., 1984. Twodimensional NMR studies of cyperene. Organ. Magn. Reson. 22, 308-311.

Kawakami, S., Toyoda, H., Harinantenaina, L., Matsunami, K., Otsuka, H., Shinzato, T., Takeda, Y., Kawahata, M., Yamaguchi, K., 2013. Eight new diterpenoids and two new norditerpenoids from the stems of Croton cascarilloides. Chem. Pharm. Bull. 61, 4114148.

Kuo, Y.-H., Yu, M.-T., 1999. Four new sesquiterpenes from the heartwood of Juniperus formosana var. concolor. Chem. Pharm. Bull. 47, 1017-1019. 
Langat, M.K., Crouch, N.A., Smith, P.J., Mulholland, D.A. 2011. Cembranolides from the leaves of Croton gratissimus. J. Nat. Prod. 74, 2349-2355.

Langat, M.K., Crouch, N.A., Pohjala, L., Tammela, P., Smith, P.J., Mulholland, D.A. 2012.

Ent-kauren-19-oic acid derivatives from the stem bark of Croton pseudopulchellus Pax. Phytochem. Lett. 2012, 5, 414-418.

Li, Y., Carbone, M., Vitale, R. M., Amodeo, P., Castelluccio, F., Sicilia, G., Mollo, E., Nappo, M., Cimino, G., Guo, Y.-W., Gavagnin, M. Rare casbane diterpenoids from the Hainan soft coral Sinularia depressa. J. Nat. Prod. 2010, 73, 133-138.

Liu, C.-P., Xu, J.-B., Zhao, J.-X., Xu, C.-H., Dong, L., Ding, J., Yue, J.-M., 2014.

Diterpenoids from Croton laui and their cytotoxic and antimicrobial activities. J. Nat. Prod. 77, 1013-1020.

Lopes, M. I. L., Saffi, J., Echeverrigaray, S., Henriques, J. A. P., Salvador, M., 2004.

Mutagenic and antioxidant activities of Croton lechleri sap in biological systems. J. Ethnopharmacol. 95, 437-445.

Maslovskaya, L.A., Savchenko, A.I., Pierce, C.J., Gordon, V.A., Reddell, P.W., Parsons, P.G., Williams, C.M., 2014. Unprecedented 1,14-seco-crotofolanes from Croton inularis: Oxidative cleavage of crotofolin $\mathrm{C}$ by a putative homo-Baeyer-Villiger rearrangement. Chem. Eur. J. 20, 14226-14230.

McChesny, J. D., E.R.Silveira, 1990. ent-Clerodanes of Croton sonderlanus. Fitoterapia LXI, 172.

Mohagheghzadeh, A., Faridi, P., Shams-Ardakani, M., Ghasemi, Y., 2006. Medicinal smokes. J. Ethnopharmacol. 108, 161-184.

Mulholland, D.A., Langat, M.K., Crouch, N.R., Coley, H.M., Mutambi, E.M., Nuzillard, J.M., 2010. Cembranolides from the stem bark of the southern African medicinal plant, Croton gratissimus. Phytochemistry 71, 1381-1386.

Muthee, J. K., Gakuya, D. W., Mbaria, J. M., Kareru, P. G., Mulei, C. M., Njonge, F. K., 2011. Ethnobotanical study of anthelmintic and other medicinal plants traditionally used in Loitoktok district of Kenya. J. Ethnopharmacol. 135, 15-21.

National Cancer Institute DTP Developmental Therapeutics Program. 2016, https://dtp.cancer.gov/discovery_development/nci-60/methodology.html_ (accessed 21/3/2016).

Ndunda, B., Langat, M.K., Eastman, H., Walker, L.A., Muhammad, I., Mulholland, D.A., Kerubo, L.O., Midiwo, J., 2016. New ent-clerodane and abietane diterpenoids from the roots of the Kenyan Croton megalocarpoides Pax. Planta Med. 82, 1079-1086 
Ngadjui, B. T., Folefoc, G. G., Keumedjio, F., Dongo, E., Sondengam, B. L., Connolly, J. D., 1999. Crotonadiol, a labdane diterpenoid from the stem barkof Croton zambesicus. Phytochemistry 51, 171-174.

Pudhom, K., Sommit, D., 2011. Clerodane diterpenoids and a trisubstituted furan from Croton oblongifolius. Phytochem. Lett. 4, 147-150.

Repetto, G., del Peso, A., Zurita, J. L., 2008. Neutral red uptake assay for the estimation of cell viability/cytotoxicity. Nat. Protoc. 3, 1125-1131.

Robien, W. http://nmrpredict.orc.univie.ac.at/similar/eval.php (accessed 14/06/2016)

Salatino, A., Salatino, M. L. F., Negri, G., 2007. Traditional uses, chemistry and pharmacology of Croton species (Euphorbiaceae). J. Braz. Chem. Soc. 18, 11-33.

Shang, S.-Z., Kong, L.-M., Yang, L.-P., Jiang, J., Huang, J., Zhang, H.-B., Shi, Y.-M., Zhao, W., Li, H.-L., Luo, H.-R., Li, Y., Xiao, W.-L., Sun, H.-D., 2013. Bioactive phenolics and terpenoids from Manglietia insignis. Fitoterapia 84, 58-63.

Sollmann, T., 1920. A sketch of the medical history of Dragon's blood. J. Am. Pharm. Assoc. 9, 141-144.

Suárez, A. r. I., Compagnone, R. S., Salazar-Bookaman, M. M., Tillett, S., Delle Monache, F., Di Giulio, C., Bruges, G., 2003. Antinociceptive and anti-inflammatory effects of Croton malambo bark aqueous extract. J. Ethnopharmacol. 88, 11-14.

Tchissambou, L., Chiaroni, A., Riche, C., Khuong-Huu, F., 1990. Crotocorylifuran and crotohaumanoxide, new diterpenes from Croton haumanianus J. Leonard. Tetrahedron 46, 5199-5202.

Thongtan, J., Kittakoop, P., Ruangrungsi, N., Saenboonrueng, J., Thebtaranonth, Y., 2003. New antimycobacterial and antimalarial 8,9-secokaurane diterpenes from Croton kongensis. J. Nat. Prod. 66, 868-870.

$\mathrm{Xu}$, Y., Zhang, H.-W., Wan, X.-C., Zou, Z.-M., 2009. Complete assignments of ${ }^{1} \mathrm{H}$ and ${ }^{13} \mathrm{C}$ NMR data for two new sesquiterpenes from Cyperus rotundus L. Magn. Reson. Chem. 47, 527-531. 


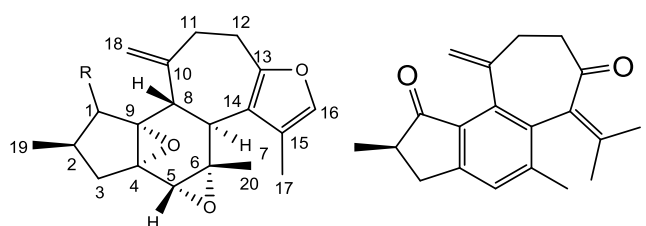

$1 \mathrm{R}=\beta \mathrm{OAC}$

$2 \mathrm{R}=\mathrm{=}$

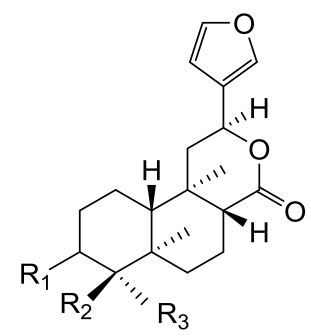

3
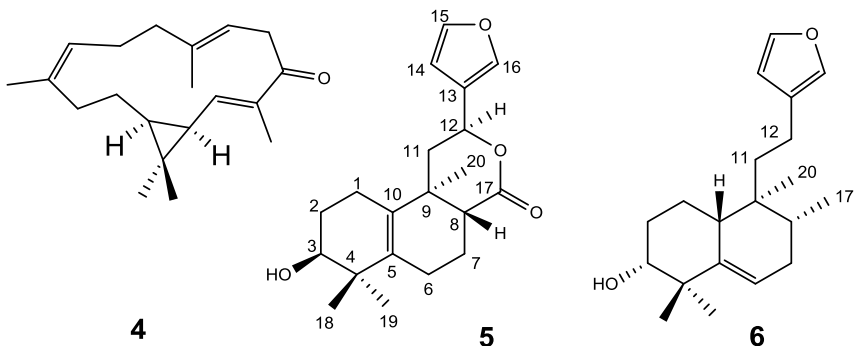<smiles>C[C@]12CC[C@@H]3C(=O)O[C@@H](c4ccoc4)C[C@H]3[C@@H]1CC[C@H]1O[C@H]12</smiles><smiles>[R]C1CC[C@H]2[C@@H](CCc3ccoc3)[C@H](C)CC[C@@]2(C)C1([R2])[R]</smiles><smiles>C[C@H]1CC[C@@]2(C)[C@@H]3O[C@H]3CC[C@H]2[C@@H]1CCc1ccoc1</smiles>

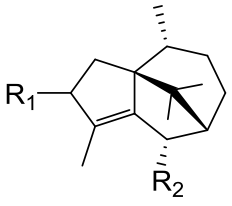

$7 \mathrm{R} 1=\alpha \mathrm{OH}, \mathrm{R}_{2}=\mathrm{OH}, \mathrm{R} 3=\mathrm{CH}_{3}$

$8 \mathrm{R}_{1}==\mathrm{O}, \mathrm{R}_{2}=\mathrm{H}, \mathrm{R}_{3}=\mathrm{CH}_{3}$

$9 \mathrm{R}_{1}=\alpha \mathrm{OH}, \mathrm{R}_{2}+\mathrm{R}_{3}==\mathrm{CH}_{2}$

$1011 \mathrm{R}_{1}=\alpha \mathrm{OH}, \mathrm{R}_{2}+\mathrm{R}_{3}==\mathrm{CH}_{2}$

13

$14 \mathrm{R}_{1}=\mathrm{H}, \mathrm{R}_{2}=\mathrm{H}$

$12 \mathrm{R}_{1}==\mathrm{O}, \mathrm{R}_{2}=\mathrm{H}, \mathrm{R}_{3}=\mathrm{CH}_{3}$

$15 \mathrm{R}_{1}==\mathrm{O}, \mathrm{R}_{2}=\mathrm{H}$

$16 \mathrm{R}_{1}=\mathrm{H}, \mathrm{R}_{2}=\mathrm{OCH}_{3}$

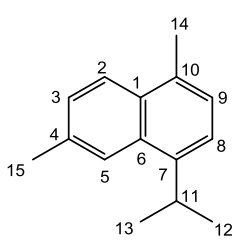

17<smiles>Cc1ccc(C(C)C)c2c1CC[C@](C)(O)[C@H]2O</smiles>

18<smiles>Cc1ccc2c(c1)[C@](O)(C(C)C)CC[C@]2(C)O</smiles>

19

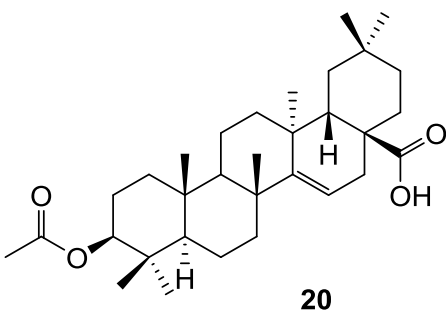

20

Figure 1. Compounds isolated from the roots of Croton dichogamus 


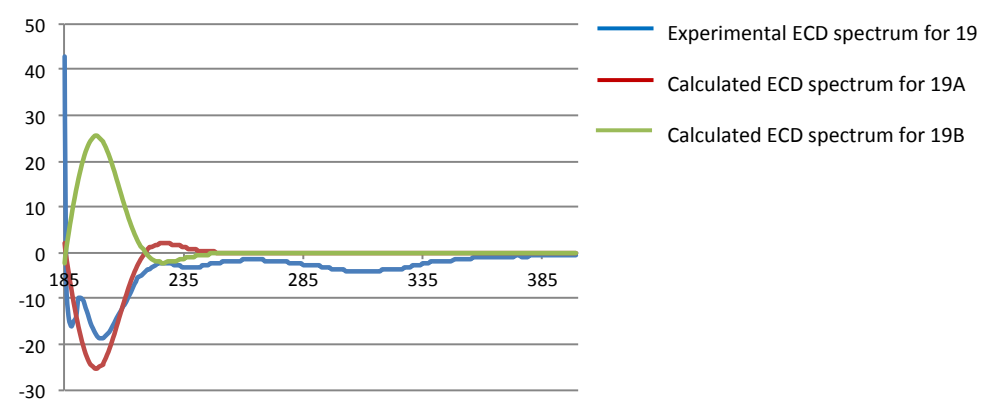

Figure 2: Experimental ECD spectrum for compound 19 (blue) and TDDFT simulated spectra for 19a (red) and 19b (green). (Units for the $y$-axis are $(\Delta \varepsilon)$ and $\lambda(\mathrm{nm})$ for the $x$ axis.)

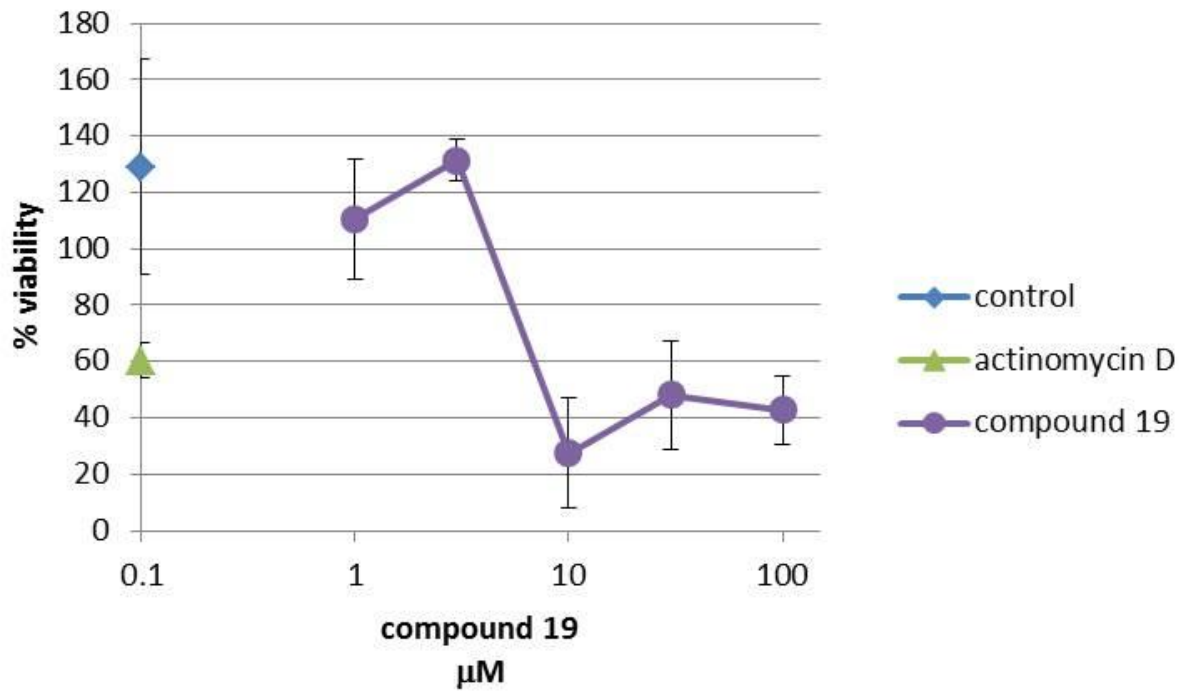

Figure 3: Effect of compound 19 on Caco-2 cell viability after 48 hours. Viability relative to vehicle (0.1\% DMSO)-treated cells is shown. Mean values with standard deviation are plotted from $\mathrm{N}=2(1-30 \mu \mathrm{M})$ or $\mathrm{N}=3(100 \mu \mathrm{M})$ experiments. Actinomycin D $(10 \mu \mathrm{g} / \mathrm{ml})$ was used as the positive cytotoxic control. 
Table 1. NMR spectroscopic Data (500 $\left.\mathrm{MHz}, \mathrm{CDCl}_{3}\right)$ of compounds 1-3

\begin{tabular}{|c|c|c|c|c|c|c|c|c|c|}
\hline \multicolumn{4}{|c|}{1} & \multicolumn{3}{|c|}{2} & \multicolumn{3}{|c|}{3} \\
\hline position & $\delta_{\mathrm{C}, \text { type }}$ & $\delta_{\mathrm{H}}(J$ in $\mathrm{Hz})$ & HMBC & $\delta_{\mathrm{C}}$, type & $\delta_{\mathbf{H}}(J$ in $\mathrm{Hz})$ & HMBC & $\delta_{\mathrm{C}}$, type & $\delta_{\mathrm{H}}(J$ in $\mathrm{Hz})$ & HMBC \\
\hline 1 & $75.3, \mathrm{CH}$ & $5.50, \mathrm{~d}(5.6)$ & $2,3,4,8,9$ & $206.1, \mathrm{C}$ & & & $208.0, \mathrm{C}$ & & \\
\hline 2 & $33.8, \mathrm{CH}$ & $2.21, \mathrm{~m}$ & 3,19 & $38.7, \mathrm{CH}$ & $2.49, \mathrm{~m}^{a}$ & $1,3,4,9,19$ & $42.9, \mathrm{CH}$ & $2.72, \mathrm{~m}^{a}$ & $1,3,9,19$ \\
\hline $\begin{array}{l}3 \mathrm{a} \\
3 \mathrm{~b}\end{array}$ & 37.2, $\mathrm{CH}_{2}$ & $\begin{array}{l}2.47, \mathrm{dd}^{a}(13.7,7.3) \\
1.64, \mathrm{dd}(13.7,7.3)\end{array}$ & $\begin{array}{l}1,2,4,9 \\
1,2,4,5,19\end{array}$ & $31.2, \mathrm{CH}_{2}$ & $\begin{array}{l}2.66, \mathrm{dd}(14.0,8.3) \\
1.84 \mathrm{dd}(14.0,6.8)\end{array}$ & $\begin{array}{l}1,2,4,9,19 \\
1,2,4,9,19\end{array}$ & $34.4, \mathrm{CH}_{2}$ & $\begin{array}{l}3.34, \mathrm{dd}(16.8,8.0) \\
2.66, \mathrm{~m}\end{array}$ & $\begin{array}{l}1,2,4,5,9,19 \\
2,4,5,9,19\end{array}$ \\
\hline 4 & $60.7, \mathrm{C}$ & & & $65.8, \mathrm{C}$ & & & 131.0, C & & \\
\hline 5 & $57.8, \mathrm{CH}$ & $3.14, \mathrm{~s}$ & $3,4,6,9,20$ & $56.2, \mathrm{CH}$ & $3.29, \mathrm{~s}$ & $4,6,9,20$ & $126.9, \mathrm{CH}$ & $7.22, \mathrm{~s}$ & $3,4,6,7,9,20$ \\
\hline 6 & $57.4, \mathrm{C}$ & & & $61.5, \mathrm{C}$ & & & 137.9, C & & \\
\hline 7 & $41.8, \mathrm{CH}$ & $2.80, \mathrm{~d}(12.5)$ & $\begin{array}{l}5,6,8,9,10,13,14 \\
15,20\end{array}$ & $49.0, \mathrm{CH}$ & $2.49, \mathrm{~d}^{a}(13.0)$ & $6,8,9,10,13,14,15,20$ & 143.4, C & & \\
\hline 8 & $37.1, \mathrm{CH}$ & $3.06, \mathrm{~d}(12.5)$ & $6,7,9,10,11,18$ & $39.9, \mathrm{CH}$ & $2.78, \mathrm{~d}^{a}(13.0)$ & $4,6,7,8,9,10,14,18$ & 139.2, C & & \\
\hline 9 & $69.0, \mathrm{C}$ & & & $66.1, \mathrm{C}$ & & & 153.3, C & & \\
\hline 10 & $145.3, \mathrm{C}$ & & & $141.9, \mathrm{C}$ & & & $142.0, \mathrm{C}$ & & \\
\hline $11 \mathrm{a}$ & $36.5, \mathrm{CH}_{2}$ & $2.58, \mathrm{~m}$ & $8,10,12,18$ & $37.8, \mathrm{CH}_{2}$ & $2.53, \mathrm{~m}$ & $8,10,12,13,18$ & $31.7, \mathrm{CH}_{2}$ & $2.82, \mathrm{~m}$ & $8,10,12,13,18$ \\
\hline $11 \mathrm{~b}$ & & $2.47, \mathrm{~m}^{a}$ & $8,10,12,13,18$ & & $2.78, \mathrm{~m}^{a}$ & $10,12,13,18$ & & $2.72, \mathrm{~m}^{a}$ & $8,10,12,13,18$ \\
\hline $12 \mathrm{a}$ & 22.9, $\mathrm{CH}_{2}$ & $2.98, \mathrm{~m}$ & $11,13,14$ & 23.1, $\mathrm{CH}_{2}$ & $2.81, \mathrm{~m}$ & $10,11,14$ & $40.9, \mathrm{CH}_{2}$ & $2.27, \mathrm{~m}$ & $10,11,13,14$ \\
\hline $12 \mathrm{~b}$ & & $2.77, \mathrm{~m}$ & $10,11,13$ & & $2.95, \mathrm{~m}$ & $10,11,13,14$ & & $2.43, \mathrm{~m}$ & $10,11,13$ \\
\hline $\begin{array}{l}13 \\
14\end{array}$ & $\begin{array}{l}150.4, \mathrm{C} \\
122.3, \mathrm{C}\end{array}$ & & & $\begin{array}{l}150.4, \mathrm{C} \\
121.8, \mathrm{C}\end{array}$ & & & $\begin{array}{l}202.5, \mathrm{C} \\
134.3, \mathrm{C}\end{array}$ & & \\
\hline 15 & 117.5, C & & & 117.0, C & & & 147.5, C & & \\
\hline 16 & $137.0, \mathrm{CH}$ & 7.0, brs (3.49) & $13,14,15$ & $137.0, \mathrm{CH}$ & $7.03, \mathrm{~s}$ & $13,14,15,17$ & $23.5, \mathrm{CH}_{3}$ & $1.49, \mathrm{~s}$ & $14,15,17$ \\
\hline 17 & $8.8, \mathrm{CH}_{3}$ & 1.96 , brs $(2.53)$ & $14,15,16$ & $8.9, \mathrm{CH}_{3}$ & $1.96, \mathrm{~s}$ & $14,15,16$ & $22.1, \mathrm{CH}_{3}$ & $2.13, \mathrm{~s}$ & $14,15,16$ \\
\hline 18 & $114.1, \mathrm{CH}_{2}$ & 4.91, brs $(4.93)$ & $8,10,11$ & $116.9, \mathrm{CH}_{2}$ & $5.06, \mathrm{~s}$ & $8,10,11$ & $114.8, \mathrm{CH}_{2}$ & $5.26, \mathrm{~s}$ & \\
\hline 18 & & 5.01, brs $(4.85)$ & $8,10,11$ & & 4.67 , brs & $8,10,11$ & & 4.93 , brs & \\
\hline 19 & $12.8, \mathrm{CH}_{3}$ & $0.91, \mathrm{~d}(7.1)$ & $1,2,3$ & 16.0, $\mathrm{CH}_{3}$ & $1.11, \mathrm{~d}(7.5)$ & $1,2,3$ & $16.1, \mathrm{CH}_{3}$ & $1.28, \mathrm{~d}(7.1)$ & $1,2,3$ \\
\hline 20 & $20.2, \mathrm{CH}_{3}$ & $1.08, \mathrm{~s}$ & $5,6,7$ & $20.3, \mathrm{CH}_{3}$ & $1.09, \mathrm{~s}$ & $5,6,7$ & 20.6, $\mathrm{CH}_{3}$ & $2.21, \mathrm{~s}$ & $8,10,11$ \\
\hline
\end{tabular}

$\mathrm{COCH}_{3} \quad 20.8, \mathrm{CH}_{3} \quad 2.11, \mathrm{~s}$

$1, \mathrm{COO}$

${ }^{a}$ Overlapping values 
Table 2. NMR spectroscopic Data (500 $\mathrm{MHz}, \mathrm{CDCl}_{3}$ ) of compounds 5, 6, 11 and 19

\begin{tabular}{|c|c|c|c|c|c|c|c|c|}
\hline \multicolumn{3}{|c|}{5} & \multicolumn{2}{|r|}{6} & \multicolumn{2}{|l|}{11} & \multicolumn{2}{|l|}{19} \\
\hline position & $\delta_{\mathrm{C} \text {, type }}$ & $\delta_{\mathrm{H}}(J$ in $\mathrm{Hz})$ & $\delta_{\mathrm{C}}$, type & $\delta_{\mathrm{H}}(J$ in $\mathrm{Hz})$ & $\delta_{\mathrm{C}}$, type & $\delta_{\mathrm{H}}(J$ in $\mathrm{Hz})$ & $\delta_{\mathrm{C}}$, type & $\delta_{\mathrm{H}}(J$ in $\mathrm{Hz})$ \\
\hline 1 & $24.3, \mathrm{CH}_{2}$ & $2.08, \mathrm{~m}$ & $37.1, \mathrm{CH}_{2}$ & $\begin{array}{l}1.55, \mathrm{~m}^{a} \\
1.68, \mathrm{~m}\end{array}$ & $16.9, \mathrm{CH}_{2}$ & $\begin{array}{l}1.83, \mathrm{dd}(3.2,12.8) \\
1.47, \mathrm{~m}^{\mathrm{a}}\end{array}$ & $137.6, \mathrm{C}$ & \\
\hline $\begin{array}{l}2 \alpha \\
2 \beta\end{array}$ & 27.3, $\mathrm{CH}_{2}$ & $\begin{array}{l}1.66, \mathrm{~m} \\
1.81, \mathrm{~m}\end{array}$ & $28.5, \mathrm{CH}_{2}$ & $\begin{array}{l}1.72, \mathrm{~m} \\
1.89, \mathrm{~m}\end{array}$ & $34.9, \mathrm{CH}_{2}$ & $\begin{array}{l}2.03, \mathrm{~m} \\
1.57, \mathrm{~m}\end{array}$ & $120.9, \mathrm{CH}$ & $7.21, \mathrm{~d}^{\mathrm{a}}(8.0)$ \\
\hline $\begin{array}{l}3 \\
4\end{array}$ & $\begin{array}{l}75.9, \mathrm{CH} \\
39.8, \mathrm{C}\end{array}$ & 3.46, dd $(11.7,3.3)$ & $\begin{array}{l}76.6, \mathrm{CH} \\
41.5, \mathrm{C}\end{array}$ & 3.49, brs $\left(W_{1 / 2} 8.6\right)$ & $\begin{array}{l}74.9, \mathrm{CH} \\
161.0, \mathrm{C}\end{array}$ & 4.34, brs $\left(W_{1 / 2} 7.8\right)$ & $\begin{array}{l}128.2, \mathrm{CH} \\
137.5, \mathrm{C}\end{array}$ & $7.18, \mathrm{~d}(8.0)$ \\
\hline 5 & $135.1, \mathrm{C}$ & & $142.5, \mathrm{C}$ & & $40.1, \mathrm{C}$ & & $122.5, \mathrm{CH}$ & $7.20, \mathrm{~s}^{a}$ \\
\hline $6 \alpha$ & $25.0, \mathrm{CH}_{2}$ & $2.11, \mathrm{~m}$ & $121.0, \mathrm{CH}$ & 5.56, brd $(10.8)$ & $38.1, \mathrm{CH}_{2}$ & $1.72, \mathrm{~m}$ & $138.9, \mathrm{C}$ & \\
\hline $6 \beta$ & & $2.22, \mathrm{~m}$ & & & & $1.47, \mathrm{~m}^{\mathrm{a}}$ & & \\
\hline $\begin{array}{l}7 \alpha \\
7 \beta\end{array}$ & 18.6, $\mathrm{CH}_{2}$ & $\begin{array}{l}1.60, \mathrm{~m}^{a} \\
2.30, \mathrm{~m}^{a}\end{array}$ & $32.0, \mathrm{CH}_{2}$ & $\begin{array}{l}1.85, \mathrm{~m} \\
1.90, \mathrm{~m}\end{array}$ & 27.3, $\mathrm{CH}_{2}$ & $\begin{array}{l}1.46, \mathrm{~m}^{\mathrm{a}} \\
1.52, \mathrm{~m}\end{array}$ & $80.2, \mathrm{C}$ & $\begin{array}{l}2.36 \text {, ddd }(13.0,9.6,3.5) \\
1.49, \mathrm{dt}(12.4,3.9,)\end{array}$ \\
\hline $\begin{array}{l}8 \mathrm{a} \\
8 \mathrm{~b}\end{array}$ & $48.3, \mathrm{CH}$ & $2.31, \mathrm{~m}^{a}$ & $33.7, \mathrm{CH}$ & $1.62, \mathrm{~m}$ & $36.8, \mathrm{CH}$ & & $24.4, \mathrm{CH}_{2}$ & $\begin{array}{l}2.36 \text {, ddd }(13.0,9.6,3.5) \\
1.49 \text {, dt }(12.4,3.9)\end{array}$ \\
\hline $\begin{array}{l}9 \mathrm{a} \\
9 \mathrm{~b}\end{array}$ & $37.0, \mathrm{C}$ & & $37.4, \mathrm{C}$ & & $39.5, \mathrm{C}$ & $1.17, \mathrm{dd}(1.9,12.1)$ & $30.5, \mathrm{CH}_{2}$ & $\begin{array}{l}1.59, \mathrm{dt}(12.4,3.9) \\
2.26, \mathrm{ddd}(13.0,9.6,3.5)\end{array}$ \\
\hline 10 & $132.1, \mathrm{C}$ & & $39.0, \mathrm{CH}$ & $2.31, \mathrm{~m}$ & $48.9, \mathrm{CH}$ & $1.63, \mathrm{~m}$ & 75.9, C & \\
\hline $11 \alpha$ & 41.1, $\mathrm{CH}_{2}$ & $2.32, \mathrm{~m}$ & 20.3, $\mathrm{CH}_{2}$ & $1.56, \mathrm{~m}^{a}$ & $38.8, \mathrm{CH}_{2}$ & $1.51, \mathrm{~m}$ & $30.6, \mathrm{CH}$ & 2.60, hep (6.9) \\
\hline $11 \beta$ & & $1.82, \mathrm{~m}$ & & & & $2.29, \operatorname{td}(4.5,13.5)$ & & \\
\hline $\begin{array}{l}12 \\
13\end{array}$ & $\begin{array}{l}72.4, \mathrm{CH} \\
125.9, \mathrm{C}\end{array}$ & $5.47, \mathrm{dd}(12.0,5.0)$ & $\begin{array}{l}18.5, \mathrm{CH}_{2} \\
125.9, \mathrm{C}\end{array}$ & $2.36, \mathrm{~m}$ & $\begin{array}{l}18.5, \mathrm{CH}_{2} \\
125.9, \mathrm{C}\end{array}$ & $2.13, \operatorname{td}(4.5,13.5)$ & $\begin{array}{l}17.1, \mathrm{CH}_{3} \\
18.7, \mathrm{CH}_{3}\end{array}$ & $\begin{array}{l}1.15, \mathrm{~d}(6.9) \\
1.21, \mathrm{~d}(6.9)\end{array}$ \\
\hline 14 & $108.8, \mathrm{CH}$ & 6.42, brs $\left(W_{1 / 2} 4.0\right)$ & $111.2, \mathrm{CH}$ & 6.28, brs $\left(W_{1 / 2} 3.9\right)$ & $111.2, \mathrm{CH}$ & 6.24, brs $\left(W_{1 / 2} 3.9\right)$ & $19.3, \mathrm{CH}_{3}$ & $1.64, \mathrm{~s}$ \\
\hline $\begin{array}{l}15 \\
16\end{array}$ & $\begin{array}{l}143.9, \mathrm{CH} \\
139.7, \mathrm{CH}\end{array}$ & $\begin{array}{l}7.41, \text { brs }\left(W_{1 / 2} 4.1\right) \\
7.45, \text { brs }\left(W_{1 / 2} 3.7\right)\end{array}$ & $\begin{array}{l}143.0, \mathrm{CH} \\
138.6, \mathrm{CH}\end{array}$ & $\begin{array}{l}7.35, \text { brs }\left(W_{1 / 2} 4.0\right) \\
7.22, \text { brs }\left(W_{1 / 2} 3.8\right)\end{array}$ & $\begin{array}{l}142.9, \mathrm{CH} \\
138.6, \mathrm{CH}\end{array}$ & $\begin{array}{l}7.34, \text { brs }\left(W_{1 / 2} 4.0\right) \\
7.19, \text { brs }\left(W_{1 / 2} 3.8\right)\end{array}$ & $21.9, \mathrm{CH}_{3}$ & $2.41, \mathrm{~s}$ \\
\hline 17 & $172.8, \mathrm{C}$ & & 15.3, $\mathrm{CH}_{3}$ & $0.88, \mathrm{~d}(6.7)$ & 16.3, $\mathrm{CH}_{3}$ & $0.83, \mathrm{~d}\left(W_{1 / 2} 6.0\right)$ & & \\
\hline 18 & $20.4, \mathrm{CH}_{3}$ & $0.98, \mathrm{~s}$ & 28.6, $\mathrm{CH}_{3}$ & $1.07, \mathrm{~s}$ & 109.7, $\mathrm{CH}_{2}$ & $\begin{array}{l}4.87, \operatorname{brs}\left(W_{1 / 2} 3.0\right) \\
4.81, \text { brs }\left(W_{1 / 2} 3.2\right)\end{array}$ & & \\
\hline 19 & $24.5, \mathrm{CH}_{3}$ & $1.07, \mathrm{~s}$ & $25.7, \mathrm{CH}_{3}$ & $1.15, \mathrm{~s}$ & $23.2, \mathrm{CH}_{3}$ & $1.26, \mathrm{~s}$ & & \\
\hline${ }^{20} \mathrm{Ov}$ & $\begin{array}{l}20.3, \mathrm{CH}_{3} \\
\text { rlapping }\end{array}$ & $\begin{array}{l}1.19, \mathrm{~s} \\
\text { alues }\end{array}$ & $16.4, \mathrm{CH}_{3}$ & $0.71, \mathrm{~s}$ & $18.4, \mathrm{CH}_{3}$ & $0.79, \mathrm{~s}$ & & \\
\hline
\end{tabular}

